\title{
A diet for slimming?
}

\author{
BY CAROL A. BOWYER \\ Department of Nutrition and Dietetics, St George's Hospital, London SW17 OQT
}

At this point in time there has never been so much information on slimming. The latest diet, treatment programme, slimming food, supplement or exercise plan can be found in a multitude of books, magazines and on video. A book on slimming was a top ten seller in both 1988 and 1989. Anybody, it appears, who has lost weight can write about their 'method' and, depending on how famous they are or how active their public relations company is, stands to make a lot of money.

Slimming is a multi-million pound business which continues to grow. And yet, from information recently published by the Department of Health from a survey carried out by the Office of Population Censuses and Surveys (OPCS, 1990), obesity is increasing. There are $12 \%$ of women and $8 \%$ of men who have a body mass index (BMI) over 30 compared with 8 and $6 \%$ respectively a decade ago. The increase is far more marked in women than in men.

The fashion press is beginning to recognize that the British woman is getting larger, with a greater demand for clothes sizes described as outsize in the industry but, perhaps, becoming average for British women. Whilst not wishing to confuse women who buy these larger clothes sizes with clinical obesity, when the role model of the popular fashion magazines continues to look like an 'anorectic clothes hanger', it is not surprising the slimming industry is so large. Morris et al. (1989) reported a tendency for fashion models' shapes to have become less curvaceous and more tubular over the past 20 years. However, this is not the forum to discuss size and weight control in relation to the fashion industry; the title of the present paper is $A$ diet for slimming?, with a question mark after it. It is presented as a question because of the uncertainty of there being a 'diet for slimming' which stands on its own and would fulfil all the criteria I have in mind for successful treatment of obesity. I want to consider some of the features of a slimming diet which are expected from it, and whether they are reasonable or not. I have drawn extensively on my clinical experience as a dietitian working with the overweight population.

There has been a multitude of slimming diets (Table 1). All have one aim, which is to decrease total energy intake. Therefore, all involve an energy restriction, but there are 'good' and 'bad' ways of going about that. Those advising the user to eat a very limited choice of foods, such as eating bananas and eggs only, tend to be self-limiting and few people are likely to continue for long. From a nutritional point of view they are not to be recommended. It is interesting that aspects of some of these fad and crash diets tend to linger; for example, the value of grapefruit in burning up fat.

In 1862 William Banting lost $46 \mathrm{lb}$ in 1 year consuming a high-protein, lowcarbohydrate diet. This consisted chiefly of lean meat, fish and between four and six glasses of good red wine, sherry or madeira every day (Buist, 1965). If we get beyond starvation which was resurrected by Bloom in the late 1950s, Simeons (1954) published his dietary prescription which consisted of two high-protein, low-carbohydrate meals daily of $50 \%$ protein, $20 \%$ carbohydrate and $30 \%$ fat by energy (Table 2 ). 
Table 1. Examples of slimming diets

$\begin{array}{ll}\text { The Grapefruit Diet } & \text { The BBC Diet } \\ \text { Low Carbohydrate Diet } & \text { The Biogenic Diet } \\ \text { Beverley Hills Diet } & \text { The Rotation Diet } \\ \text { Scarsdale Diet } & \text { Cambridge Diet } \\ \text { Guilt-free Diet } & \text { The Hip and Thigh Diet } \\ \text { Chocolate Lovers Diet } & \text { HPLC Diet } \\ \text { F-Plan Diet } & \text { Nibblers Diet } \\ \text { Microdiet } & \end{array}$

Table 2. Menu for each meal (from Simeons (1954))

\begin{tabular}{lll}
\hline \hline & $100 \mathrm{~g}$ \\
& Lean meat & 1 helping \\
& Leaf vegetables & 1, small \\
& Unsweetened rusk & 1 \\
& Apple & ad lib. \\
\hline
\end{tabular}

In the $1960 \mathrm{~s}$, for a time, fat became the nutrient to eat if you wanted to lose weight, with the concept of 'eat fat and grow thin', with fat allowed freely and carbohydrate restricted. However, with a carbohydrate restriction fat is not enormously palatable eaten on its own, and total energy intake is likely to be decreased; hence the so-called high-fat diet is in reality a low-carbohydrate one.

It is the low-carbohydrate diet that has stayed for so long. Users were recommended to restrict foods containing carbohydrate to below $50 \mathrm{~g} / \mathrm{d}$, so they become ketotic. In addition the initial diuresis as a result of decreasing carbohydrate intake severely was seen as an initial motivator to continue. This diet was recommended by Professor Yudkin at the First Symposium of The Obesity Association held in London in 1968 (Yudkin, 1969). Yudkin stated, 'As regards reduction in calorie intake, all considerations lead to the conclusion that for most people the low carbohydrate regime is the most satisfactory'. Those were the days of the slimmer eating steak and salad followed by cheese! The hangover from this is that many people continue to regard bread and potatoes as fattening foods. The dietary prescription at this time in the textbook of the student dietitian, Human Nutrition and Dietetics (Davidson \& Passmore, 1966) was a $4.2 \mathrm{MJ}$ (1000 kcal) regimen (about $24 \%$ protein, 37\% carbohydrate, 36\% fat by energy).

Most energy-controlled diets are prescribed in the region of 3.4-6.3 MJ (800-1500 $\mathrm{kcal}$ ) with an emphasis on avoiding foods high in energy but low in nutrient-density, i.e. those foods high in fat and sugar. A diet lower in energy than $3.4 \mathrm{MJ}$ is likely to be nutritionally inadequate with respect to protein, vitamin and mineral content. However, a diet of $4.2 \mathrm{MJ}$ will need to be chosen well, if adhered to consistently, to meet the Department of Health's recommended daily amounts for vitamins and minerals for groups (Department of Health and Social Security, 1979). We do not know the requirements of the weight-losing individual.

In the 1970s the buzz word was fibre, and Audrey Eyton (1982) put beans on toast on many a slimming Briton's meal-table with the popular F-Plan Diet. Although fibre was extolled with a few too many magical properties, this diet had many good things to 
recommend it. The F-Plan Diet consisted of a higher carbohydrate intake in the form of fibrous starch. The nutritional messages from the 1980s taking us into the 1990s are eat more starch, less sugar and less fat. The slimming diet, therefore, simply changes shape, becoming 'The Great Pasta Diet' or 'Slim with Potatoes', or 'Hip and Thigh Diet', which is basically a low-fat regimen.

As a dietitian the four words I frequently hear from the overweight population are 'the diet doesn't work'. Why are they saying this? What isn't working? Expectations of rate of weight loss is the biggest contributory factor to this statement. So often patients sit in front of clinicians and say, 'I only lost a couple of pounds this week', with disappointment in their voice.

The literature for the very-low-calorie diet (VLCD) was aimed at those for whom conventional 4.2 MJ regimens 'didn't work' and formula, liquid diets containing only $1.38 \mathrm{MJ}(330 \mathrm{kcal})$ supplemented with vitamins and minerals flooded onto the UK market in the early $1980 \mathrm{~s}$. For the person who could not lose weight on $4.2 \mathrm{MJ} / \mathrm{d}$, by using a VLCD, they could expect to lose $2-3 \mathrm{~kg}$ every week on $2.9 \mathrm{MJ} / \mathrm{d}$ less! With the publication of the Committee on Medical Aspects of Food Policy (COMA) report on the use of VLCD in obesity (Department of Health and Social Security, 1987) following concerns regarding the safety of these products, it was recommended VLCD preparations provide a minimum of $1.68 \mathrm{MJ}(400 \mathrm{kcal}) / \mathrm{d}$ for women and $2.1 \mathrm{MJ}(500 \mathrm{kcal}) / \mathrm{d}$ for men and tall women (over $1.73 \mathrm{~m}$ ) and should provide respectively 40 and $50 \mathrm{~g}$ of suitable protein. In addition those people with a BMI below 25 should not use a VLCD.

An integral part of education regarding weight loss has to include people understanding in order to lose $0 \cdot 5-1 \mathrm{~kg}$ or $1-2 \mathrm{lb} /$ week demands an energy deficit of $2 \cdot 1-4 \cdot 2 \mathrm{MJ} / \mathrm{d}$ (taking each $\mathrm{kg}$ of excess weight to represent about $29.4 \mathrm{MJ}$ stored energy). This may effectively be easier for the more severely overweight whose requirements are much larger but becomes more difficult for the person who has less to lose. Garrow (1981) suggests rates of weight loss greater than $1 \mathrm{~kg} /$ week is at the expense of losing excess lean tissue, as seen in starvation. This would have implications for metabolic requirements when weight is lost.

That invites the question of how can the optimum energy deficit be accurately created when an individual's initial energy requirements are not known. The tool of the dietitian's trade in assessment is the dietary history whereby eating behaviour and pattern can be identified and energy intake be quantified. Time - and a skilled interviewer - are needed.

However, thin or fat, it is very easy to forget what and how much we eat in $1 \mathrm{~d}$. The study of Acheson et al. (1980) in the Antarctic is a reminder of how people, even in a reasonably controlled environment, do not report their dietary intake accurately retrospectively and will underestimate it. The subjects did so predominantly by underestimating portion sizes and mid-meal snacks. When they were given a blank sheet of paper they underestimated on average by $33 \%$, whilst if they were given a printed dietary questionnaire it was $21 \%$.

It is often easier for people to recall what they have eaten at meal-times, as it is a clearly defined time to eat, particularly if it follows a regular pattern. Foods eaten between meals are far more easily forgotten because people are frequently doing something else at the same time, e.g. eating biscuits with coffee whilst working, eating chocolate bought from the garage, having filled the car with petrol, eating crisps whilst watching television, the children's left-overs, and so on. The list is endless. 
Table 3. Why do you eat?

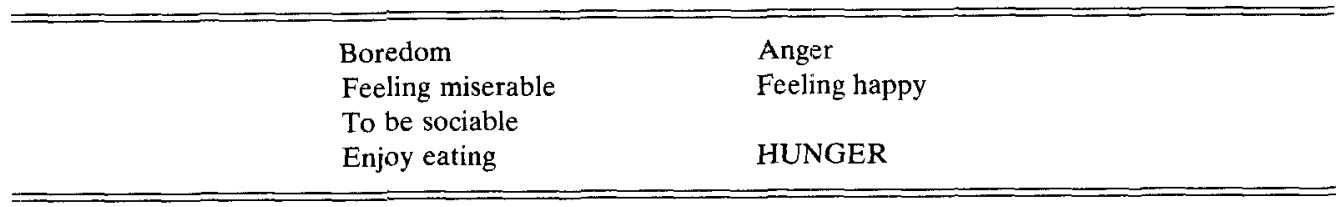

Table 4. Why the diet didn't work

\author{
'It's my metabolism' \\ 'It's my glands' \\ 'The Doctor said I had the slowest metabolism of anyone he had met' \\ 'I went to a wedding two weeks ago' \\ 'I've been told my body defies the law of energetics!'
}

In addition to the difficulty of recall, other needs in people's lives are frequently met with food. I asked a group of women at a slimming club why they ate, and they gave reasons as listed in Table 3. The women agreed between themselves that hunger was often the last reason for which they ate.

Table 4 lists reasons given to me from overweight patients as to why the 'diet didn't work'.

Garrow et al. (1978), whilst at Northwick Park Hospital, reported of those patients who failed to lose weight whilst claiming to eat only $3.4 \mathrm{MJ}$ as outpatients, who were subsequently admitted into his metabolic ward, with its tight security, always lost weight. Prentice et al. (1986), using the doubly-labelled-water method, showed his overweight subjects to be under-recording their intake by $3.5 \mathrm{MJ} / \mathrm{d}$.

Without an objective measurement of energy requirements, how much of the picture can the dietitian obtain?

Also, without having a clear idea of the eating patterns of the overweight population, how can a slimming diet be formulated to meet their needs?

It seems to me an even bigger problem to slimming is staying slimmer and Stunkard's (1958) well-known conclusion, having evaluated the outcome of treatment for obesity in the previous 30 years, still rings true today: 'Most obese people do not enter treatment for obesity. Of those who do enter, most will not remain. Of those who remain, most will not lose much weight. Of those who lose weight, most will regain it'. To maintain a lower weight demands lifelong changes to eating habits and lifestyle.

Short-term crash diets have no basis on which permanent change can be made as, in the main, they are not nutritionally adequate and on the whole are not designed to help the user lose weight permanently. The way they are used is likely to be for only a short time, for example before a family wedding, before a holiday, that is, frequently before a feast.

If the overweight are going to effect long-term change they need to move away from the word 'diet'. Comments such as 'I am on a diet' or 'I am off it' are linked to frugal eating or overeating. Being 'on a diet' is suggestive of short-term change if previous habits are reinstated when 'off the diet'. Slimmers get into the habit of 'I am dieting' or 'I am not', i.e. 'I am losing weight' or 'I am failing'. Statements such as 'I shall never eat 


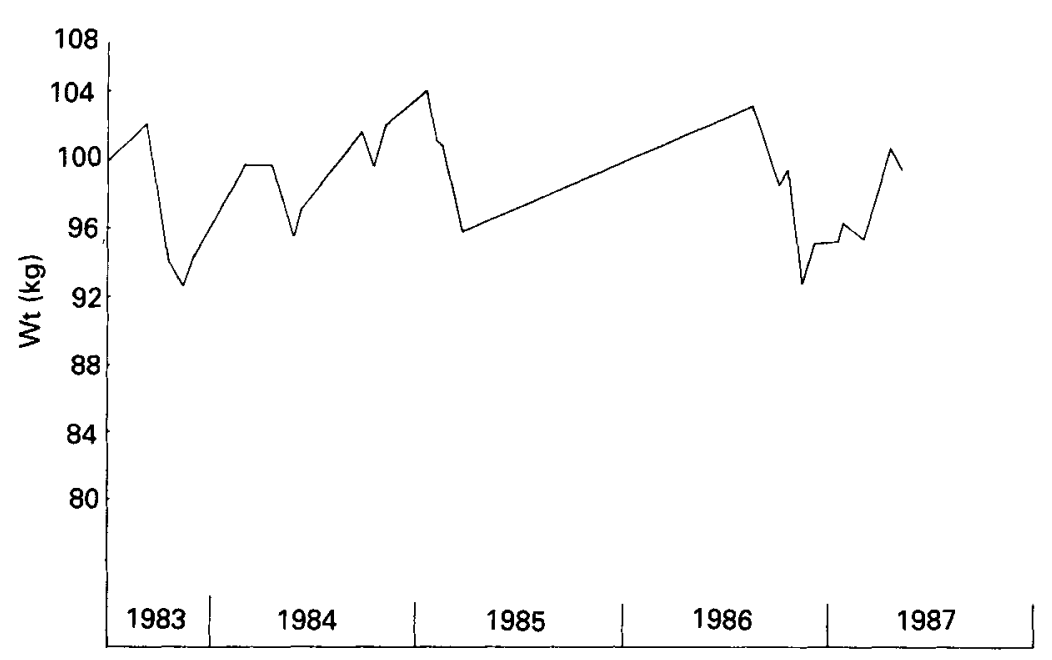

Fig. 1. Weight chart of subject M.J. reconstructed from slimming club records.

another biscuit' are unrealistic. The slimmer frequently starts her day with good intentions and skips breakfast, eats fruit for lunch, arriving home starving hungry and eats all evening.

When people attempt to severely restrict their food intake they put themselves into a situation of dietary restraint. This restraint is more likely to lead to compensatory overeating or binge-eating. This in turn makes people feel guilty, out of control, reinforcing feelings of failure and low self-esteem. They resolve to diet more strictly and the cycle is perpetuated.

The term yo-yo dieting is applied to those losing weight and constantly regaining it. In Wandsworth Health Authority we looked at some of our long-term attenders at the slimming club run by the Community Dietitian and Health Visitor which has been in operation for well over 10 years. The weight chart in Fig. 1 is of a 50-year-old woman (M.J.) taken from the club's records, and is typical of a yo-yo dieter; each time she rejoined the club she had regained all she had previously lost and, 4 years later, was at an identical weight.

By the very nature of our professional title dietitians are linked with the treatment of obesity. The word 'diet' is always associated with slimming entirely, outside of the profession. You only have to stand next to someone at a party and say you are a dietitian to hear how much weight they have, have not or wish to lose!

Within Wandsworth Health Authority we looked at the number of outpatients, in 1 month, who were in treatment for obesity (Fig. 2). Looking at these in terms of degree of obesity, using Garrow's (1981) classification by grade using BMI, the majority, at that point in time, were in grades I and II (Table 5). Of the patients $96 \%$ were referred to the Nutrition and Dietetic Department. One extremely soul-destroying fact coming out of this data collection was the high level of failures to attend, equivalent that month to $18 \mathrm{~h}$ dietetic time equal to 2.5 full working days. But I know, as a profession, we are not alone in having such a high attrition rate treating this population.

So this large number of patients was referred to the same professional with a request 
How large is the problem of obesity

in Wandsworth Health Authority?

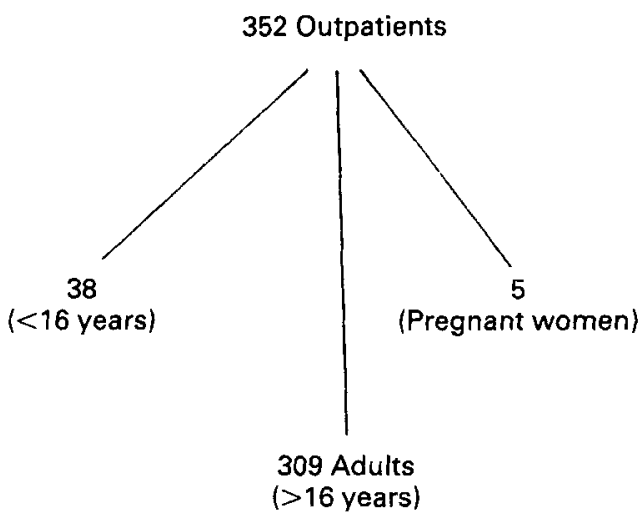

Fig. 2. Number of outpatients, who were in treatment for obesity, seen in 1 month by Wandsworth Health Authority.

Table 5. Classification by grade, using body mass index (BMI) (Garrow, 1981), of outpatients treated for obesity by Wandsworth Health Authority

\begin{tabular}{lcrc}
\hline \hline & BMI & $n$ & $\begin{array}{c}\text { Percentage } \\
\text { of total }\end{array}$ \\
\hline Grade 0 & $20-24 \cdot 9$ & 4 & 1 \\
Grade I & $25-29 \cdot 9$ & 97 & 31 \\
Grade II & $30-40$ & 138 & 45 \\
Grade III & $>40$ & 34 & 11 \\
Incomplete data & & 36 & 12 \\
Total & 309 & 100 \\
\hline
\end{tabular}

for virtually the same treatment: a diet. This included the young woman with a BMI of 24 told she would 'feel better' losing weight, to the man described as 'grossly obese with dependent oedema' with a BMI of 48 . Would the $4 \cdot 2 \mathrm{MJ}$ diet outlined by a dietitian from a London teaching hospital in 1963 (24\% protein, 33\% carbohydrate and $43 \%$ fat by energy) or the 'Healthy Eating Plan' ( $20 \%$ protein, $48 \%$ carbohydrate and $32 \%$ fat by energy) used in Wandsworth Health Authority in 1990 work for both? From a nutritional point of view the former has a higher percentage of protein and fat energy and far less carbohydrate than the 'Healthy Eating Plan' which concentrates predominantly on decreasing fat whilst recommending an increase in carbohydrate in the form of starch and is, therefore, nutritionally superior with respect to the recommendations of today (National Advisory Committee on Nutrition Education, 1983; Department of Health and Social Security, 1984).

But if so many people regard being 'on a diet' as short term, will it be of any greater benefit to either user? If we could all pass either of these advice sheets outlining adequate energy-controlled diets to the overweight population with the expectation they would be 


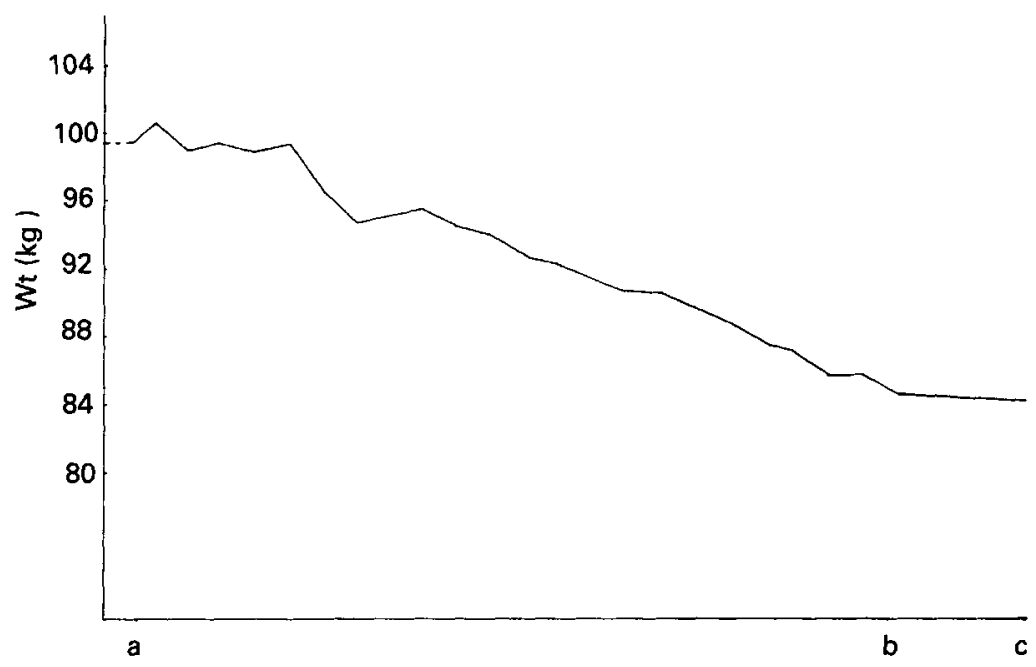

Fig. 3. Weight chart of subject M.J. during a twenty-session treatment programme over 40 weeks showing (a) beginning of treatment, (b) end of treatment, (c) 8-week follow-up.

adhered to implicitly, we might as a profession be influential in decreasing the incidence of obesity with a slimming diet alone.

Mrs M.J. from the slimming club, whose weight chart is shown in Fig. 1, had no difficulty following dietary advice and losing weight, but she did not maintain it. Group support enabled her to lose weight when she attended the groups only. I offered her one-to-one time-limited number of sessions using psychological techniques to help her control clearly defined bingeing episodes related to mood. She responded and, as can be seen from the weight chart in Fig. 3, lost weight far more slowly than at the slimming group but she had maintained it at follow-up. After 9 months she weighed only $3 \mathrm{~kg}$ more than at the end of treatment. She ate more to lose weight, and we put a greater emphasis on meal pattern and structure and less on her need for rapid weight loss.

At the Fourth International Conference on Eating Disorders held in April of this year M. D. Marcus and D. E. Smith (unpublished results) reported that of those individuals presenting for treatment at their clinic, $40 \%$ were described as obese bulimics and had not responded to conventional dietary management for weight loss.

If we consider the overall dietary strategies in the past three decades, slimming diets have concentrated on the avoidance of a single major nutrient, e.g. carbohydrate, and we have reached near-starvation levels of VLCD. The message has been weight loss has to be rapid and the female population, in particular, has been on and off diets in a growing slimming market. And yet, as I began by saying, the British population is getting fatter. Perhaps our efforts in the next decade should be concentrated on getting the message across of slow, sustained nutritional change.

Obesity carries serious health risks and within the Health Service the condition needs to be recognized as doing so. I favour a multi-disciplinary approach to treatment which includes appropriate assessment of needs rather than the rather blanket prescription to very large numbers of people to 'go on a slimming diet'. 


\section{REFERENCES}

Acheson, K. J., Campbell, I. T., Edholm, O. G., Miller, D. S. \& Stock, M. J. (1980). The measurement of food and energy intake in man - an evaluation of some techniques. American Journal of Clinical Nutrition 33, $1147-1154$.

Buist, J. S. (1965). Mr Banting's 'Excellent Adviser'. Practitioner 194, 415-420.

Davidson, S. \& Passmore, R. (1966). Human Nutrition and Dietetics, 3rd ed., p. 798. Edinburgh and London: E. and S. Livingstone Ltd.

Department of Health and Social Security (1979). Recommended daily amounts of food energy and nutrients for groups of people in the United Kingdom. Report on Health and Social Subjects no. 15. London: H.M. Stationery Office.

Department of Health and Social Security (1984). Committee on Medical Aspects of Food Policy report on diet and cardiovascular disease. Report on Health and Social Subjects no. 28. London: H.M. Stationery Office.

Department of Health and Social Security (1987). Committee on Medical Aspects of Food Policy report on the use of very low calorie diets in obesity. Report on Health and Social Subjects no. 31. London: H.M. Stationery Office.

Eyton, A. (1982). The F-Plan. London: Penguin Books.

Garrow, J. S. (1981). Treat Obesity Seriously: A Clinical Manual, p. 22. Edinburgh and London: Churchill Livingstone.

Garrow, J. S., Durrant, M. L., Mann, S., Stalley, S. F. \& Warwick, P. (1978). Factors determining weight loss in obese patients in a metabolic ward. International Journal of Obesity 2, 441-447.

Morris, A., Cooper, T. \& Cooper, P. J. (1989). The changing shape of female fashion models. International Journal of Eating Disorders 8, 593-596.

National Advisory Committee on Nutrition Education (1983). Proposals for Nutritional Guidelines for Health Education in Britain. London: Health Education Council.

Office of Population Censuses and Surveys (1990). The Dietary and Nutritional Survey of British Adults. London: H.M. Stationery Office.

Prentice, A. M., Black, A. E., Coward, W. A., Davies, H. L., Goldberg, G. R., Murgatroyd, P. R., Ashford, J., Sawyer, M. \& Whitehead, R. G. (1986). High levels of energy expenditure in obese women. British Medical Journal 292, 983-987.

Simeons, A. T. W. (1954). The action of chorionic gonadotrophin in the obese. Lancet ii, 946-947.

Stunkard, A. J. (1958). The management of obesity. New York Journal of Medicine 58, 79_87.

Yudkin, J. (1969). The treatment of obesity. In Obesity Medical and Scientific Aspects, p. 92 [I. McLean Baird and A. N. Howard, editors]. Edinburgh and London: E. and S. Livingstone Ltd. 